\title{
Socially Responsible Investing: Moral and Optimal?
}

\author{
By
}

Padma Kadiyala ${ }^{\aleph}$

This Version: November 22, 2004

JEL Codes: G11, G12, G14

\footnotetext{
" Please address all correspondence to: Padma Kadiyala, Lubin School of Business, Pace University, 861 Bedford Road, Pleasantville, NY 10570, Ph:914 773 3620, email:pkadiyala@pace.edu.
} 


\begin{abstract}
I evaluate the performance of static and dynamic strategies involving socially responsible investments (SRI). I show that although the average SRI fund underperforms a market index, a portfolio that accounts for time variation in the number of SRI funds available to investors, actually outperforms the market index. An examination of the dynamic performance of the SRI portfolio shows that returns to SRI funds are less sensitive to unanticipated shifts in the business cycle than the returns to a market portfolio. I show that a sector rotation strategy which involves timing business cycle shifts by reallocating between the CRSP index and the SRI portfolio earns a positive and statistically significant return. Finally, I find weak evidence that an SRI investment represents a flight to quality during periods of high relative risk aversion.
\end{abstract}




\section{INTRODUCTION}

The Social Investment Forum (SIF) defines socially responsible investing (SRI) as integrating personal values and societal concerns with investment decisions. Statman (2000) provides a description of the exclusionary and qualitative screens that are applied by funds that adhere to SRI. The SIF claims that socially responsible investing allows an investor to earn a competitive return while 'working to build a better tomorrow'. Geczy, Stambaugh and Levin (2003) perform utility calculations to test this claim. They find that for an investor who believes strongly in the Capital Asset Pricing Model (CAPM) of Sharpe (1964) and Lintner (1965), the cost of imposing the SRI constraint reduces the Sharpe ratio by a few basis points a month.

Anecdotal evidence suggests that SRI funds may outperform a passive index during certain periods in time. The TIAA social fund outperformed TIAA's equity index fund by 3.21\% over the five year period ended Sept. 30, 2004. In Figure 1, I plot the number of SRI funds offered each year from 1992 to 2003 against the annual return to a proxy for the market portfolio, the value weighted CRSP index. The graph shows that the number of SRI mutual funds offered each year is negatively correlated with the return to the CRSP index. These correlations are particularly evident in the years 2002 and 2003. The number of SRI funds reached its maximum of 69 funds in the year 2002 when the return on the CRSP index was $-21.49 \%$. The number of SRI funds dropped to 68 when the return on the CRSP index increased in 2003.

I construct a portfolio of SRI funds that accounts for these temporal variations in the number of SRI funds offered each year. Each month, starting in 1992, and ending in 2003, I invest $\$ 100$ in a portfolio which consists of a $\$ 1$ investment in each SRI fund that 
was available in January of that calendar year. Any money left over is invested in the market portfolio. I find that the portfolio constructed in this manner has a lower standard deviation than a conventional portfolio that invests an equal amount in each SRI fund that is available in that month. The modified portfolio has the property that it holds the fraction of total wealth invested in a particular SRI fund constant through time. Such a portfolio replicates more closely a practical investment approach and is shown in this paper to outperform the passive CRSP value weighted index.

The modified SRI portfolio is weighted towards small, value stocks. Fama and French (1996) show that the size and value factors have significant explanatory power for the cross section of stock returns. I adjust the returns to the SRI portfolio for these risk factors using a three-factor model. I find that the SRI portfolio does not earn abnormal returns after these risk adjustments.

The static performance of an SRI investment does not provide strong justification in favor of an investment in a constrained portfolio. I next examine whether an investment in an SRI portfolio can be justified by its conditional performance. I postulate that a higher weighting in family friendly businesses reduces the sensitivity of SRI returns to unanticipated shifts in the business cycle. I test the hypothesis by estimating a GMM regression of SRI returns on instrumental variables that capture business cycle shifts. I compare the coefficients obtained from this regression against those obtained from a similar regression for the CRSP value weighted index return. Wald tests show support for the hypothesis; the coefficients obtained for SRI returns are significantly smaller than those obtained with market returns. I test a second hypothesis that the demand for SRI funds is positively related to changes in risk aversion. By restricting 
their investments to socially responsible stocks, SRI funds limit their exposure to companies that are more likely to be subject to costly litigation. I predict that a 'flight to quality' during periods of higher risk aversion reduces the expected return to an SRI portfolio. This hypothesis is tested by determining how a change in the level of real wealth relative to historical levels affects the expected return to the SRI portfolio. I find that the expected return to the SRI portfolio decreases when the relative level of risk aversion increases, but the negative relation is only marginally significant.

Existing empirical studies on the optimality of an SRI investment have been inconclusive. Hamilton, Jo and Statman (1993) were one of the earliest studies to examine the performance of SRI funds. They find that from 1981 to 1990, the average SRI fund underperforms a market portfolio, but does not significantly underperform conventional mutual funds. Statman (2000) finds similar evidence over a more recent period from 1990 through 1998. Derwall, Guenster, Bauer, and Koedijk (2004) use Innovest's corporate eco-efficiency scores to construct their own SRI portfolios and find that the high-ranked portfolio outperformed the low-ranked portfolio over the period from 1995 to 2003. Bauer, Koedijk, and Otten (2002) show that the performance of an international sample of ethical mutual funds is qualitatively similar to SRI funds based in the US.

This paper's focus on the merits of SRI investing is closely related to recent research on whether capital markets reward businesses that focus on the societal impact of their business policies. Andersen and Reeb (2003) show that family controlled businesses perform better than non-family firms. The authors argue that families' reputational concerns increase the firm's awareness of the long-term economic 
consequences of its policies. Heinkel, Kraus and Zechner (2001) model how a boycott by ethically conscious investors can raise the cost of capital for polluting firms.

The rest of this paper is organized as follows. In section 2 , we describe the data on SRI mutual funds. In section 3, we present evidence on the performance of SRI funds. In section 4 , we examine the business cycle sensitivity of these funds. In section 5, we examine the sensitivity of SRI funds to changes in relative risk aversion. In section 6, we study the profitability of trading strategies. In section 7 , we conclude.

\section{Data}

I compiled the list of socially responsible mutual funds and pension funds from two sources: Morningstar and the Social Investment Forum webpage. There are 143 funds listed on Morningstar and 90 funds listed on the SIF webpage. Combining the two sources and eliminating duplicates yields 211 funds. Multiple share classes of funds are eliminated retaining only the main share class. After eliminating bond funds, GNMA, REIT, tax-exempt, money-market, international and global funds, I am left with a final sample of 123 funds. I matched this sample with the CRSP mutual fund database, and was able to obtain monthly returns for 72 funds.

These funds are listed in Table 1. Table 1 also reports the beginning and ending year of existence of each fund. Most funds are short lived having been instituted on or after the year 2000. Nine funds have been in existence for between five and 10 years, four funds have been in existence for between 10 and 20 years, and two funds have been in existence for more than 20 years. The largest fund in terms of total net assets under management is the Pioneer II fund ( $\$ 4.9$ billion) followed by the AARP Growth and

Income fund ( $\$ 4.18$ billion). The Bridgeway Fund earned the highest return of $2.06 \%$ per 
month, but since it had been in existence for only four years, we cannot conclude that it was the best performing in the SRI category. The longest running SRI fund, the Stratton Growth fund earned an average return of $1.04 \%$ per month.

I compute various measures of portfolio performance for the SRI funds listed in Table 1. The Sharpe ratio is calculated as the ratio of the average monthly excess lifetime return earned by the fund to its standard deviation. Table 1 also presents for comparison the Sharpe ratio for the CRSP index. Data on the risk-free rate of return and the market return were obtained from the Fama-French dataset.

Table 1 shows that 28 out of the 74 funds had a higher Sharpe index than the market portfolio. The Stratton Growth Fund, the longest running SRI fund was one of the outperformers with a Sharpe ratio of 0.174 compared to a ratio of 0.137 for the market index. The Bridgeway Ultra Small Company portfolio earned the highest Sharpe ratio of 0.320 , handily outperforming the market portfolio which earned a Sharpe ratio of only 0.179 over the same time interval.

The Sharpe ratio measures the reward per unit of standard deviation, which includes both systematic and non-systematic risk. We isolate the reward per unit of systematic, or beta risk, by reporting the Treynor index in Table 1 . The Treynor index is the ratio of the average excess return and the beta. For the market portfolio, the Treynor index is just the average excess return. The market beta for each SRI fund is the coefficient obtained from an OLS regression of the excess portfolio return on the excess return to the CRSP index. Table 1 shows that 27 SRI funds had a higher Treynor index than the market portfolio, the same proportion as funds that had a higher Sharpe index. Finally, we report Jensen's alpha which is the intercept from the OLS regression. 
Jensen's alpha is the abnormal return earned by the portfolio under the null hypothesis that the CAPM is the equilibrium pricing model. 27 funds had positive alphas. The highest alpha $(1.7 \%$ per month) is earned by Bridgeway Fund: Micro-cap limited portfolio.

Table 1 shows that less than a third of all SRI funds reliably outperform the market index. Even so, this evidence does not conclusively demonstrate that the SRI constraint adversely affects performance. Statman (2000) and Goldreyer and Diltz (1999) show that the performance of SRI funds is no worse than that of conventional mutual funds. A second consideration is that there have only been five SRI funds that have been in continuous existence for at least 10 years. A majority (almost $2 / 3$ rds) of all SRI funds have been in existence for only three years at most. A three-year history is insufficient to calculate an unbiased estimate of the true performance of the average SRI fund. Exogenous factors such as strategic choices made by fund management as to when to open or close an SRI fund can also impact performance. It was shown in Figure 1 that the number of SRI funds offered in a given year increases just prior to a downmarket. It may be the case that many of the SRI funds are created in response to investing fads rather than as a vehicle for long term investors interested in pursuing a SRI philosophy. For such investors, the alternative to selecting an individual SRI mutual fund is to invest in a portfolio of SRI funds.

\section{Static Performance of SRI portfolios}

I construct a conventional equal weighted portfolio of SRI funds. An equal dollar amount is invested in each SRI fund that was available each month starting in January 1992 and ending in December 2003. The portfolio is rebalanced in the following month. 
Univariate statistics on the performance of this portfolio, 'Portfolio 1' are reported in Table 2. The mean monthly return to this portfolio is $0.80 \%$ and the median return is $0.97 \%$. The mean and the median return to 'portfolio 1' are lower than the corresponding returns to the CRSP index. A lower mean return combined with a higher standard deviation leads to a lower Sharpe ratio $(0.1365)$ for the SRI portfolio than for the CRSP index (0.137). When the beta risk alone is considered, the SRI portfolio does not underperform the CRSP index. The Treynor index for 'Portfolio 1' and for the CRSP index are both equal to 0.006 . Portfolio 1 earns a positive alpha of $0.01 \%$ per month, but the alpha is statistically insignificant.

The standard deviation of 'Portfolio 1' reported in Table 2 is biased since the composition of the portfolio includes a progressively higher number of individual SRI funds. In 1992 there were only five SRI funds in existence, a number which jumped to 63 by January of 2000 . The changing composition of the portfolio affects the standard deviation of returns in the following manner: the standard error of the portfolio is proportional to $\sigma / \sqrt{N}$ where $\sigma$ is the standard deviation of the average SRI fund and $\mathrm{N}$ is the number of funds in the portfolio. 'Portfolio 1' is characterized by an increasing number of funds comprising the portfolio, which means that the standard error of the portfolio is higher in the early part of the sample, and is lower towards the end.

I construct a portfolio of SRI funds that takes into account the time series variation in the number of SRI funds offered in a given year. In each month starting in January 1992 and ending in December 2003, I create a $\$ 100$ portfolio which invests a dollar in every SRI fund that was available in January of that calendar year. Any money that is left over is invested in the CRSP value weighted index. The portfolio is rebalanced 
in the following month. If a fund that was available in January ceases to exist mid-year, I substitute the CRSP index for the missing fund till the end of the calendar year. It is dropped from the portfolio in subsequent years.

By holding the investment constant at $\$ 100$, I hold the weight on each SRI fund constant even as the number of SRI funds increases. Thus on January 1992, when there were 5 SRI funds in existence, the weight on each fund is $1 \%$. In January of 2000 , when the number of SRI funds had increased to 63 , the weight on each fund remained at $1 \%$. The constant weight placed on each fund in 'Portfolio 2' stands in contrast to the decreasing weight placed on each fund in the composition of 'Portfolio 1'. A fund that was in existence in January of 1992 received a weight of $20 \%$ in 'Portfolio 1', which decreased to $1.5 \%$ by January of 2000 . 'Portfolio 2' represents a more realistic approach to SRI investing than 'Portfolio 1'. It is unlikely that an investor would gradually reduce the proportion invested in a particular fund as required by 'Portfolio 1'.

The monthly return to 'portfolio 2 ' is calculated as the increase in the monthly value of the portfolio from its value of $\$ 100$ at the beginning of the month. Statistics on the performance of portfolio 2 are presented in Table 2. Portfolio 2 earns a mean return of $0.91 \%$ per month and a median return of $1.36 \%$ per month, which are both higher than the corresponding returns to 'portfolio 1'. As expected, the higher returns to 'portfolio 2' are associated with a lower standard deviation ( $4.17 \%$ per month). The combination of a higher mean and a lower standard deviation leads to a higher Sharpe ratio for 'portfolio 2' (0.1405) than for the CRSP index. 'Portfolio 2' outperforms the CRSP index even adjusting for beta risk, as indicated by the higher Treynor index (0.0061). The Jensen's alpha for 'portfolio 2 ' is $0.02 \%$ per month, which is statistically insignificant. 
The evidence in Tables 1 and 2 show that shifting trends in the industry complicate an evaluation of the performance of an SRI portfolio. The average SRI fund underperforms the index, but an SRI portfolio that recognizes the short-lived nature of the average SRI fund presents a different picture. A dynamic portfolio that is rebalanced annually such that the proportion of each SRI fund in the portfolio remains constant through time actually outperforms the CRSP index on a risk-adjusted basis.

Another complication in the evaluation of the performance of SRI funds is that these funds do not follow a uniform investment style. A perusal of fund names in Table 1 reveals that investment styles range from small-cap to large-cap, and from growth to value. There is now abundant evidence, starting with the seminal paper by Fama and French (1992), that small stocks significantly outperform large stocks, and that value stocks outperform growth stocks. The wide variation in investment styles of SRI funds across the size and value dimensions implies that the performance of SRI funds has to be adjusted for these factors.

Factor adjusted returns are obtained by estimating the following regression:

$$
\mathrm{R}_{\mathrm{SRI}, \mathrm{t}}=\alpha+\beta * \mathrm{MKT}_{\mathrm{t}}+\gamma * \mathrm{SMB}_{\mathrm{t}}+\delta * \mathrm{HML}_{\mathrm{t}}+\varepsilon_{\mathrm{t}}
$$

The three independent variables in equation (1) are MKT, the excess return to the CRSP value-weighted index, SMB, the return to a small-cap portfolio less the return to a largecap portfolio, and HML, the return to a portfolio of stocks with high book to market ratio less the return to a portfolio of stocks with a low book to market ratio. $\mathrm{R}_{\mathrm{SRI}, \mathrm{t}}$ is the return to 'portfolio 2'.

Results from an estimation of equation (1) are reported in Table 3. The coefficients on the three factors are positive and statistically significant. The coefficient 
on the MKT factor is less than $1.0(0.927)$ which indicates that the SRI portfolio has lower beta risk than the market portfolio. The coefficient on the SMB factor is positive (0.140) which shows that the SRI portfolio is weighted more towards small-cap stocks. Likewise, the positive coefficient on HML indicates that the SRI fund is weighted more towards value stocks. The regression intercept is $-0.11 \%$ which is both statistically and economically insignificant. An insignificant intercept shows that the SRI portfolio does not earn abnormal returns after adjusting for the three Fama-French factors.

The average SRI fund holds only $87 \%$ of its assets in stocks. The rest is allocated to fixed income and money market securities. For instance, the Third Avenue Value Fund, the largest value-oriented SRI fund invests only $70.3 \%$ of its assets in equities. The non-trivial holding in fixed income securities means that returns to the SRI portfolio may include a component related to a bond factor. I eliminate the bond factor from the returns to the SRI portfolio factor by adding a fourth variable, BONDRET, to the regression in equation (1). BONDRET is the monthly return to the Vanguard Bond Index Fund: Total Bond Market Portfolio. The Total Bond Market Portfolio mimics the performance of the Lehman Aggregate Bond Index, and is our proxy for the bond factor.

Results from an estimation of the four factor model are presented in Panel B of Table 3. The coefficient on BONDRET is negative, but is not statistically significant. The other coefficients are qualitatively unchanged from those in Panel A of Table 3. There is a slight increase in the adjusted $\mathrm{R}^{2}$ from $98.26 \%$ in Panel A to $98.27 \%$ in Panel B. The regression intercept continues to be statistically insignificant. 


\section{Dynamic Performance of an SRI investment}

Evidence presented thus far on the unconditional performance of SRI funds does not present a compelling case for investors to deviate from the optimal portfolio and to invest instead in a constrained portfolio such as SRI funds. Before we conclude that only altruistic motives can justify an investment in SRI funds, it is worthwhile to examine the conditional performance of such funds. Stocks that qualify for inclusion in an SRI fund tend to be family oriented businesses, which in turn cluster in some industry groups such as Food and Beverage, Clothing, Textiles, and Shoes. These industries are characterized as the non-durable sector. Boudoukh, Richardson and Whitelaw (1994) show that the production growth of industries in the consumer non-durable sector, has a low correlation with aggregate industrial production growth. If an SRI portfolio is weighted more towards non-cyclical stocks, it follows that the returns to an SRI portfolio should exhibit low correlation with aggregate output. The testable hypothesis that follows from these arguments is that returns to an SRI portfolio are less sensitive to shifts in business cycles than the market portfolio.

We adopt an instrumental variable approach to compare the business cycle sensitivities of the SRI portfolio and the market portfolio. The instrumental variables are the lagged dividend yield (LDIV), the lagged term premium (LTERM), the lagged default premium (LDEF) and the lagged return to the one-month Treasury bill (LTB). Our choice of instrumental variables is based on prior evidence that these variables capture time variations in expected returns. The dividend yield has been shown to be associated with time variation in the market risk premium, with a high dividend yield capturing a higher expected market premium (Fama and French (1988), Keim and Stambaugh (1986) 
and Campbell and Shiller (1988)). Fama and French (1989) show that the default premium varies with business cycles, being higher during recessions and lower during expansions. The term premium has also been shown to predict economic activity with a higher term premium forecasting faster economic growth. The one-month T-bill has been shown to predict short-term economic activity (Fama and Schwert (1977), Ferson (1989)). Data on instrumental variables is from the Ibbotson Database and covers the period from January 1992 to December 2000.

I estimate the following GMM model for the residual SRI return and the market return:

$$
\begin{array}{r}
\varepsilon_{\mathrm{SRI}}=\mathrm{r}_{\mathrm{SRI}, \mathrm{t}}-\mathrm{a} 0-\mathrm{a} 1 * \text { LDIV }-\mathrm{a} 2 * \mathrm{LTB}-\mathrm{a} 3 * \text { LDEF- } \mathrm{a} 4 * \text { LTERM } \\
\varepsilon_{\mathrm{MKT}}=\mathrm{r}_{\mathrm{MKT}, \mathrm{t}}-\mathrm{b} 0-\mathrm{b} 1 * \text { LDIV }-\mathrm{b} 2 * \text { LTB }-\mathrm{b} 3 * \text { LDEF- } \mathrm{b} 4 * \text { LTERM }
\end{array}
$$

$\mathrm{r}_{\mathrm{SRI}, \mathrm{t}}$ is the residual return obtained from an estimation of equation (1) with BONDRET included as a fourth independent variable, and the return to 'portfolio 2' as the dependent variable. I estimate equation (2a) with the residual, rather than the actual return to portfolio 2 in order to isolate the business cycle sensitivity of the SRI factor. It was seen in Table 3 that SRI returns have significant factor loadings on the Fama-French factors. It is therefore necessary to eliminate the component in SRI returns that is related to these factors.

The GMM technique solves for the coefficients a 0 through b4 by minimizing the quadratic form ${ }^{1}$

$$
\mathrm{Q}_{\mathrm{T}}(\theta)=\mathrm{g}_{\mathrm{T}}(\theta)^{\prime} \mathrm{W} \mathrm{g}_{\mathrm{T}}(\theta)
$$

\footnotetext{
${ }^{1}$ Campbell, Lo and Mackinlay (1997) describe the GMM technique in detail.
} 
where $\mathrm{W}$ is a positive definite $(5 \times 5)$ weighting matrix, $\mathrm{g}_{\mathrm{T}}(\theta)=\frac{1}{T} \sum_{t=1}^{T} f_{t}(\theta), \theta$ is the

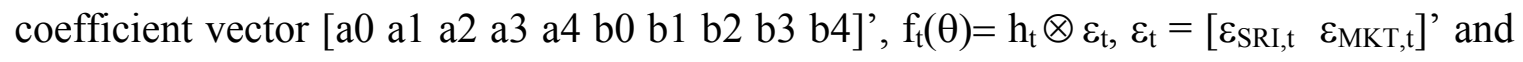
$\mathrm{h}_{\mathrm{t}}$ is the vector of instrumental variables [1 LDIV LTB LTERM LDEF] .

The SRI factor has a lower sensitivity to business cycle shifts if the coefficients al through a4 are significantly smaller than the coefficients b1 through b4. I use Wald tests to determine if the coefficients from the two equations are equal to each other. Results are presented in Table 4. Panel A of Table 4 shows that none of the coefficients in the regression with SRI returns are statistically significant. Overall, the instrumental variable model has low explanatory power for SRI returns, as indicated by an adjusted $\mathrm{R}^{2}$ of only $0.55 \%$.

In the market return regression, the coefficient on the TERM premium is negative and is statistically significant. The coefficient on the default premium is positive, but is only marginally significant. Other coefficients are statistically insignificant. Overall, the model has higher explanatory power for market returns as indicated by an adjusted $\mathrm{R}^{2}$ of $3.99 \%$.

Wald tests presented in Panel B of Table 4 confirm the relative insensitivity of SRI returns to business cycle shifts. The hypothesis that the difference in coefficients is jointly equal to zero is rejected by the Wald test. The tests also show that the coefficients on the lagged default premium and on the term premium obtained for market returns, are different from those obtained for SRI returns, at the $10 \%$ level of significance.

The conditional performance of an SRI portfolio suggests a rationale for why investors hold a constrained SRI portfolio. An SRI portfolio is a hedge against unfavorable shifts in macro-economic growth. Sector rotation strategies are practiced by 
money managers in an attempt to time shifts in business cycles. Such strategies involve decreasing the allocation to cyclical stocks at the beginning of a recession and increasing the allocation to such stocks at the start of an expansion. The results in Table 4 suggest that a sector rotation strategy can be implemented with SRI funds. The strategy would involve an increase in the allocation to the SRI portfolio at the peak of an economic expansion (in anticipation of a decline in economic growth) and a decrease in the allocation to the SRI portfolio at the trough (in anticipation of an increase in economic activity). I examine whether such a strategy is profitability later in section 6 .

\section{Flight to Quality and SRI funds}

A central tenet of the SRI philosophy is to encourage investments in businesses that follow ethical practices. Firms that are ethical in their business practices are by definition relatively secure from lawsuits which seek compensatory damages that can potentially bankrupt a company. ${ }^{2}$ A 'flight to quality' during periods of high risk aversion may increase the demand for an SRI portfolio as investors shift from higher risk to lower risk securities. The increase in demand should lead to a higher price, and therefore, to a lower expected return, for the stocks comprising an SRI portfolio. The testable hypothesis that follows is that an increase in relative risk aversion should be associated with a higher return to the SRI portfolio.

I test the hypothesis with a proxy for relative risk aversion that is based on Ilmanen (1995). The proxy, INVW is calculated as the ratio of the exponentially

\footnotetext{
${ }^{2}$ A recent example is that of Merck. "Merck's stock plunged nearly 27 percent and the company lost \$28 billion in shareholder value after the announcement (that Merck was withdrawing Vioxx)- partly in response to the loss of revenue from Merck's second best-selling drug, but also because of the lawsuits, said Richard Evans, an analyst at Sanford C. Bernstein Research. He estimates Merck's legal costs could reach $\$ 12$ billion. A new analysis by Merrill Lynch concludes Merck's liability could be as high as $\$ 17.6$ billion during the next decade or so." (see Theresa Agovino, "Merck Faces Huge Financial and Credibility fallout over Vioxx Lawsuits", Associated Press, November 4, 2004)
} 
weighted average of the past 36 months of real wealth levels to the current level of real wealth. ${ }^{3}$ The current level of real wealth is proxied by the inflation-adjusted level of the S\&P 500. A higher INVW implies a higher level of risk aversion.

The following GMM regression is estimated with INVW as an additional explanatory variable.

$$
\begin{aligned}
& \mathrm{r}_{\mathrm{SRI}, \mathrm{t}}=\mathrm{a} 0+\mathrm{a} 1 * \text { LDIV }+\mathrm{a} 2 * \text { LTB }+\mathrm{a} 3 * \text { LTERM }+\mathrm{a} 4 * \text { LDEF }+\mathrm{a} 5 * \text { INVW } \\
& \mathrm{r}_{\mathrm{MKT}, \mathrm{t}}=\mathrm{b} 0+\mathrm{b} 1 * \text { LDIV }+\mathrm{b} 2 * \text { LTB }+\mathrm{b} 3 * \text { LTERM }+\mathrm{b} 4 * \text { LDEF }+\mathrm{b} 5 * \text { INVW }
\end{aligned}
$$

I estimate equation (4a) with the residual, rather than the actual return to 'portfolio 2' for the same reason as described in the earlier section.

Results from this estimation are in Table 5. The coefficient on INVW is negative and statistically significant for SRI returns. The negative coefficient indicates that when the level of real wealth decreases relative to past wealth levels, a higher demand for the SRI portfolio lowers its expected return in the following period. The market return is insensitive to changes in the level of the risk aversion proxy as indicated by an insignificant coefficient on INVW.

Panel B of Table 5 has the Wald tests of equality of the coefficients. The Wald test rejects the hypothesis that the difference in coefficients is jointly equal to zero. But the test does not reject equality of the coefficients on INVW (p-value of 0.67). Even though, the point estimates of the coefficients on INVW for SRI and market returns are different, the difference is not statistically significant. Thus, there is only weak support

\footnotetext{
${ }^{3}$ Specifically, INVW is calculated as: $\operatorname{INVW}_{\mathrm{t}}=\frac{\left(W_{t-1}+0.9 * W_{t-2}+0.9^{2} * W_{t-3}+\ldots\right) * 0.1}{W_{t}}$, where $\mathrm{W}_{\mathrm{t}}$ is the real level of the S\&P 500 index.
} 
for the hypothesis that the expected return to the SRI portfolio decreases with an increase in risk aversion.

\section{Profitability of a sector rotation strategy}

Siegel (1991) shows that investors who can successfully forecast business-cycle turning points can earn excess stock returns of nearly $5 \%$ a year. In this section, I examine the profitability of a sector rotation strategy that involves an increase in the allocation to the SRI portfolio prior to an economic recession, and a decrease in the allocation prior to an economic expansion. That such a strategy may be profitable is suggested by the results in this paper which shows that an investment in an SRI portfolio is a hedge against macro-economic shocks.

Every month, starting in January of 1994 and ending in December of 2000, I calculate an 'excess SRI return' as the difference between the return to the modified SRI portfolio and the return to the market portfolio. Rolling regressions are estimated each month with excess SRI returns in the previous 24 months as the dependent variable and instrumental variables for changes in macro-economic conditions as the independent variables. A time series of one month ahead predicted returns is obtained from these rolling regressions as:

$$
\hat{R}_{S R I-M K T, t}=a \hat{0}+a \hat{1} * L D I V_{t-1}+a \hat{2} * L T B_{t-1}+a \hat{3} * L T E R M_{t-1}+a \hat{4} * L D E F_{t-1}
$$

where $a \hat{1}, a \hat{2}, a \hat{3}$ and $a \hat{4}$ are the coefficients obtained from each rolling regression.

I calculate the realized excess return earned by the SRI portfolio in those months when the return predicted by equation (5) is positive. The mean and median excess realized returns in those months are presented in Table 6. The realized mean excess return is $0.324 \%$ per month and is statistically significant. The median return is smaller 
$(0.0482 \%$ per month), but is also statistically significant. Thus, the SRI portfolio outperforms the market portfolio when the instrumental variables predict a decrease in economic activity. Investors who wish to hedge against such a decrease can earn positive returns by shifting their allocation to the SRI portfolio, and away from the market portfolio.

The previous section showed weak evidence that the expected return to an SRI portfolio decreases when the level of relative risk aversion increases. I examine the profitability of a strategy that times changes in economic activity as well as changes in risk aversion. I estimate monthly rolling regressions as before, but with an additional independent variable, INVW, the proxy for the level of relative risk aversion. The onemonth ahead predicted excess return is now calculated as:

$$
\hat{R}_{S R I-M K T, t}=a \hat{0}+a \hat{1} * L D I V_{t-1}+a \hat{2} * L T B_{t-1}+a \hat{3} * L T E R M_{t-1}+a \hat{4} * L D E F_{t-1}+a \hat{5} * I N V W_{t-1}
$$

I select those months when the predicted return is positive and report the mean and median realized excess return to the SRI portfolio in Panel B of Table 6. The mean and median realized returns are lower than the returns obtained with a strategy of timing economic activity only. The mean return is $0.27 \%$ per month, but is significant only at the $10 \%$ level. The median return is $0.048 \%$ per month, and is not statistically significant. Thus, a strategy of timing both business cycle shifts and risk aversion changes is not as profitable as a strategy that times business cycle shifts alone. Table 5 provides an explanation for why it is less profitable to time risk aversion changes. Expected returns to the SRI portfolio decline when risk aversion increases, which implies that the SRI portfolio is relatively more expensive during such periods. Higher prices for stocks in the SRI portfolio reduces the profitability of a timing strategy. 


\section{Conclusions}

Socially responsible investing has endured for over a quarter of a century since the first SRI fund was introduced roughly around $1980 .{ }^{4}$ It is a puzzle that the SRI philosophy has endured despite widespread consensus among academics that an SRI investment is sub-optimal (Geczy, et al (2003)). I study the static and dynamic performance of an SRI investment to determine whether altruistic motives alone can explain the continued popularity of the SRI style. I confirm the evidence in previous studies that the average SRI mutual fund underperforms a passive market index. But I show that performance evaluation of an SRI investment is complicated by variation through time in the number of SRI funds that are available to investors. I adopt a novel approach to form a portfolio of SRI funds that recognizes this time variation in the number of SRI funds. I show that such a portfolio in fact, outperforms the market index.

The dynamic performance of an SRI investment provides a more compelling explanation for why the SRI style has endured. It is shown that an SRI portfolio is an effective hedge against unanticipated changes in economic activity. I demonstrate that a strategy of increasing the allocation to an SRI portfolio and decreasing the allocation to a market portfolio, preceding a predicted decline in economic activity is profitable.

The composition of a typical SRI portfolio suggests that an SRI fund represents a safe haven during periods of high risk aversion. I find only weak evidence to support the claim. On balance, this paper shows that the continued demand for SRI funds cannot be attributed to purely altruistic motives.

\footnotetext{
${ }^{4}$ As reported on the webpage maintained by the Domini Social Index.
} 


\section{REFERENCES}

Andersen, R., and Reeb, D., 2003, Founding Family Ownership and Firm Performance: Evidence from the S\&P 500, Journal of Finance, 58(3), 1301-1327.

Bauer, R., Koedijk, K., and Otten, R., 2002, International Evidence on Ethical Mutual Fund Performance and Investment Style, Working Paper, Maastricht University.

Boudoukh, J., Richardson, M., and Whitelaw, R., 1994, Industry Returns and the Fisher Effect, Journal of Finance, 49(5), 1595-1615.

Campbell, J., and Shiller, R., 1988, The Dividend Price Ratio and Expectations of Future Dividends and Discount Factors, Review of Financial Studies 1, 195-228.

Campbell, J., Lo, A., and MacKinlay, 1997, The Econometrics of Financial Markets, Princeton University Press.

Derwall, J., Bauer, R., Guenster, N., and Koedijk, K., 2004, Socially Responsible Investing: The Eco-Efficiency Premium Puzzle, Working Paper, Erasmus University.

Fama, E. F. and G.W. Schwert, 1977, Asset returns and inflation, Journal of Financial Economics 5, 115-146.

Fama, E. and K. French, 1988, Dividend yields and Expected Stock returns, Journal of Financial Economics, 22, 3-25.

Fama, E. and K. French, 1989, Business conditions and expected returns on stocks and bonds, Journal of Financial Economics 25, 23-49.

Fama, E. and K. French, 1992, The Cross-Section of Expected Stock Returns, Journal of Finance 47 (2),427-465.

Fama, E., and K. French, 1996, Multifactor Explanations of Asset Pricing Anomalies, Journal of Finance, 51(1), 55-84.

Ferson, W. E, 1989, Changes in expected security returns, risk and the level of interest rates, Journal of Finance 44, 1191-1218.

Geczy, C., Stambaugh, R.F., and Levin, D., 2003, Investing in Socially Responsible Mutual Funds, working paper, Wharton School, University of Pennsylvania.

Goldreyer, E., and Diltz, D., 1999, The Performance of Socially Responsible Mutual Funds: Incorporating Sociopolitical Information in Portfolio Selection, Managerial Finance 25, 23-36. 
Hamilton, S., Jo, H., and Statman, M., 1993, Doing Well While Doing Good? The Investment Performance of Socially Responsible Mutual Funds, Financial Analysts Journal, Nov/Dec, 62-66.

Heinkel, R., Kraus, A., and Zechner, J., 2001, The Effect of Green Investment on Corporate Behavior, Journal of Financial and Quantitative Analysis, 36(4), 431-449.

Ilmanen, A., 1995, Time varying expected returns in international bond markets, Journal of Finance 50, 481-506.

Keim. D., and Stambaugh, R., 1986, Predicting Returns in the Stock and Bond Markets, Journal of Financial Economics 17, 357-390.

Lintner, J., 1965, The Valuation of Risk Assets and the Selection of Risky Investments in Stock Portfolios and Capital Budgets, Review of Economics and Statistics 47, 13-37.

Sharpe, W., 1964, Capital Asset Prices: A Theory of Market Equilibrium under Conditions of Risk, Journal of Finance 19, 425-442.

Siegel, J., 1991, Does It Pay Stock Investors to Forecast the Business Cycle? Journal of Portfolio Management, 18(1), 27-34.

Statman, M., 2000, Socially Responsible Mutual Funds, Financial Analysts Journal, May/June, 30-39. 


\section{Figure 1}

Plot of number of funds adhering to the socially responsible investment (SRI) style

Data on SRI funds that were available between January 1992 and December 2003 is obtained from the Social Investment Forum webpage and Morningstar. The market proxy is the CRSP value-weighted index.

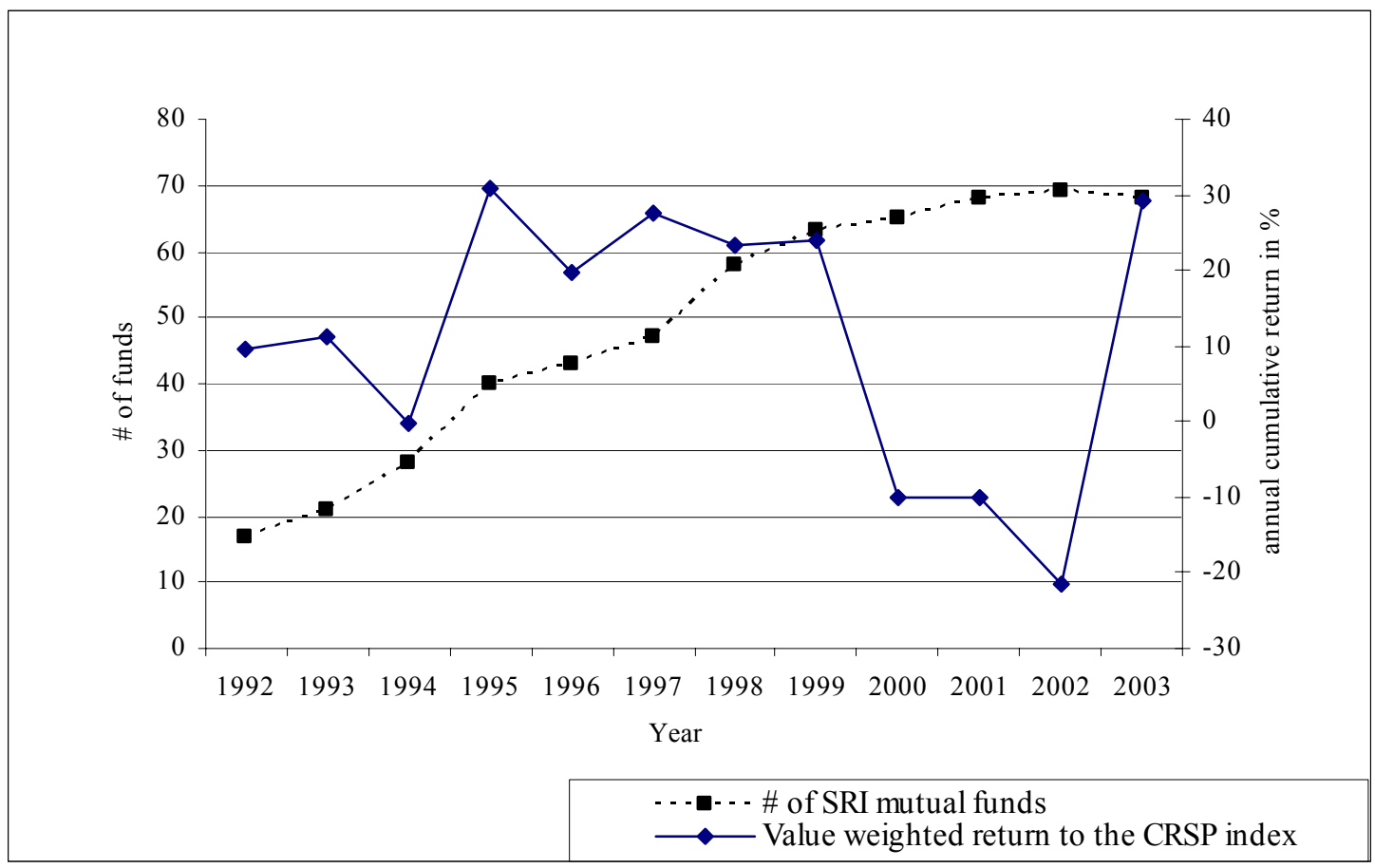


Table 1

Socially Responsible Funds

Characteristics of the 72 socially responsible funds with returns data on the CRSP mutual fund database between Jan. 1992 and Dec. 2003. 'Beg-end' is the starting and ending year for which data is available on CRSP. TNA is average total net assets of the fund during its period of existence. Load is the sum of front end, back end, and all other loads imposed by the fund. Expense is the average annual management expense charged by the fund, and, $12 \mathrm{~b}-1$ is the average $12 \mathrm{~b}-1$ fees charged by the fund. 'Return' is the average monthly return earned by each fund. The Sharpe ratio is the ratio of the average excess monthly return to each fund and the standard deviation of monthly fund returns. Jensen's alpha is the intercept obtained from an OLS regression of the excess monthly fund return on the excess return to the CRSP valueweighted index. The Treynor index is calculated as the ratio of the average excess monthly fund return to the market beta of the fund.

\begin{tabular}{|c|c|c|c|c|c|c|c|c|}
\hline Fund Name & Beg-end & $\begin{array}{r}\text { Return } \\
(\%)\end{array}$ & $\begin{array}{r}\text { TNA (\$ } \\
\mathrm{MM}) \\
\end{array}$ & $\begin{array}{l}\text { Sharpe } \\
\text { ratio of } \\
\text { market } \\
\text { portfolio }\end{array}$ & $\begin{array}{r}\text { Sharpe } \\
\text { ratio } \\
\text { for } \\
\text { fund } \\
\end{array}$ & $\begin{array}{r}\text { Jensen's } \\
\text { alpha for } \\
\text { fund }\end{array}$ & $\begin{array}{r}\text { Treynor- } \\
\text { index for } \\
\text { market } \\
\text { portfolio }\end{array}$ & $\begin{array}{r}\text { Treynor } \\
\text { index } \\
\text { for fund }\end{array}$ \\
\hline AARP Growth \& Income Fund & $93-00$ & 1.16 & 4175.17 & 0.275 & 0.238 & 0.000 & 0.010 & 0.011 \\
\hline AARP Capital Growth Fund & $93-00$ & 0.76 & 1148.41 & 0.101 & 0.060 & -0.002 & 0.004 & 0.003 \\
\hline AARP Growth Tr: Small Company Stock Fund & $98-01$ & 0.34 & 55.09 & 0.030 & 0.061 & 0.002 & 0.004 & 0.002 \\
\hline AHA Balanced Portfolio & $93-00$ & 0.83 & 40.21 & 0.061 & 0.113 & 0.001 & 0.003 & 0.006 \\
\hline AHA Diversified Equity & $94-00$ & 1.07 & 68.05 & 0.061 & 0.108 & 0.002 & 0.003 & 0.005 \\
\hline Alger Retirement Fds:Socially Resp Growth & $02-03$ & -1.25 & 0.78 & 0.089 & -0.092 & -0.012 & 0.004 & -0.005 \\
\hline Amana Mutual Funds Trust:Growth Fund & $94-00$ & 1.00 & 15.01 & 0.073 & 0.061 & 0.000 & 0.004 & 0.004 \\
\hline Amana Mutual Fund Trust-Income & $93-00$ & 0.64 & 17.11 & 0.090 & 0.053 & -0.001 & 0.004 & 0.003 \\
\hline American Trust Allegiance Fund & $99-00$ & 0.88 & 22.51 & 0.072 & 0.085 & 0.000 & 0.004 & 0.005 \\
\hline Aquinas Equity Income Fund & $96-00$ & 0.67 & 49.91 & 0.089 & 0.058 & -0.001 & 0.004 & 0.004 \\
\hline Aquinas Equity Growth Fund & $97-00$ & 0.79 & 42.72 & 0.089 & 0.082 & -0.001 & 0.004 & 0.004 \\
\hline Baron Asset Fund & $90-00$ & 1.07 & 2174.03 & 0.137 & 0.135 & 0.001 & 0.006 & 0.007 \\
\hline Baron Growth \& Income Fund & $97-00$ & 1.57 & 451.67 & 0.147 & 0.219 & 0.005 & 0.007 & 0.013 \\
\hline Baron iOpportunity Fund & $01-04$ & -0.09 & 111.38 & -0.077 & -0.030 & 0.005 & -0.004 & -0.002 \\
\hline Baron Small Cap Fund & $99-00$ & 1.16 & 612.78 & 0.033 & 0.126 & 0.006 & 0.002 & 0.008 \\
\hline Bridgeway Fund:Ultra Small Index & $01-03$ & 1.62 & 179.19 & 0.108 & 0.309 & 0.012 & 0.006 & 0.021 \\
\hline
\end{tabular}




\begin{tabular}{|c|c|c|c|c|c|c|c|c|}
\hline Fund Name & Beg-end & $\begin{array}{r}\text { Return } \\
(\%)\end{array}$ & $\begin{array}{r}\text { TNA (\$ } \\
\text { MM) }\end{array}$ & $\begin{array}{l}\text { Index- } \\
\text { Sharpe } \\
\text { ratio of } \\
\text { index }\end{array}$ & $\begin{array}{r}\text { Sharpe } \\
\text { ratio } \\
\text { for } \\
\text { fund } \\
\end{array}$ & $\begin{array}{r}\text { Jensen's } \\
\text { alpha for } \\
\text { fund }\end{array}$ & $\begin{array}{r}\text { Treynor- } \\
\text { index for } \\
\text { market } \\
\text { portfolio }\end{array}$ & $\begin{array}{l}\text { Treynor } \\
\text { index } \\
\text { for fund }\end{array}$ \\
\hline Bridgeway Fund:Ultra Large 35 Index & $01-03$ & 0.66 & 9.45 & 0.108 & 0.112 & 0.002 & 0.006 & 0.006 \\
\hline Bridgeway Fund:Ultra Small Company Portfolio & $96-00$ & 2.06 & 41.51 & 0.179 & 0.320 & 0.011 & 0.008 & 0.020 \\
\hline Bridgeway Fund:Aggressive Growth Portfolio & $97-00$ & 2.04 & 112.62 & 0.141 & 0.213 & 0.009 & 0.007 & 0.013 \\
\hline Bridgeway Fund:Social Responsibility Port & $97-00$ & 1.09 & 3.05 & 0.141 & 0.136 & 0.001 & 0.007 & 0.007 \\
\hline Bridgeway Fund:Micro-Cap Limited Portfolio & $01-03$ & 2.02 & 41.87 & 0.077 & 0.291 & 0.017 & 0.004 & 0.020 \\
\hline Calvert Ariel Growth Fund & $96-98$ & 1.10 & 492.37 & 0.137 & 0.193 & 0.004 & 0.006 & 0.014 \\
\hline Calvert Capital Accumulation Fund/A & $94-00$ & 0.95 & 87.06 & 0.139 & 0.097 & -0.001 & 0.007 & 0.005 \\
\hline Calvert Social Index Fund/A & $01-04$ & -0.61 & 24.69 & -0.070 & -0.140 & -0.003 & -0.004 & -0.008 \\
\hline Calvert Social Investments_-Managed & $96-98$ & 0.56 & 578.57 & 0.101 & 0.058 & -0.001 & 0.004 & 0.003 \\
\hline Capstone Social Ethics \& Relgs Val:Lg Cp Eq/C & $01-04$ & 0.36 & 108.48 & 0.059 & 0.015 & -0.001 & 0.003 & 0.001 \\
\hline Capstone Social Ethics \& Relgs Val:Sm Cp Eq/C & $01-04$ & 1.13 & 50.31 & 0.059 & 0.149 & 0.007 & 0.003 & 0.010 \\
\hline Catholic Values Inv Tr:Equity Fund/Individual & $99-00$ & -0.12 & 3.74 & 0.023 & -0.088 & -0.005 & 0.001 & -0.005 \\
\hline Citizens Trust:Index Portfolio & $98-99$ & 0.92 & 352.87 & 0.090 & 0.046 & -0.002 & 0.004 & 0.002 \\
\hline Cruelty Free Value Fund & $97-00$ & 0.34 & 1.6 & 0.335 & -0.014 & -0.012 & 0.017 & -0.001 \\
\hline DEVCAP Shared Return Fund & $01-03$ & 0.79 & 16.21 & 0.080 & 0.087 & 0.000 & 0.004 & 0.005 \\
\hline Delaware Social Awareness Fund/Institutional & $99-02$ & 0.54 & 0.45 & 0.015 & -0.014 & -0.002 & 0.001 & -0.001 \\
\hline Domini social index trust & $93-00$ & 0.95 & 613.31 & 0.137 & 0.140 & 0.000 & 0.006 & 0.006 \\
\hline Dominion Insight growth fund & $95-00$ & 0.72 & 12.09 & 0.094 & 0.004 & -0.006 & 0.004 & 0.000 \\
\hline Dow Jones Islamic/K & 03-04 & -0.82 & 20.2 & -0.070 & -0.168 & -0.005 & -0.004 & -0.010 \\
\hline Dreyfus Third Century Fund & $72-98$ & 0.66 & 722.71 & 0.137 & 0.068 & -0.003 & 0.006 & 0.003 \\
\hline Dreyfus Premier Third Century Fund/B & $01-04$ & -0.57 & 21.48 & -0.077 & -0.170 & -0.006 & -0.004 & -0.009 \\
\hline Flex-Partners:BTB Fund/A & $98-00$ & 0.49 & 1.86 & 0.053 & 0.055 & 0.000 & 0.003 & 0.005 \\
\hline IPS Millennium Fund & $98-00$ & 1.11 & 111.42 & 0.147 & 0.094 & -0.002 & 0.007 & 0.006 \\
\hline IPS New Frontier Fund & $01-04$ & 0.43 & 6.37 & 0.010 & 0.011 & -0.005 & 0.001 & 0.001 \\
\hline Lutheran Brotherhood Opportunity Growth Fund & $97-00$ & 0.64 & 184.56 & 0.136 & 0.043 & -0.005 & 0.006 & 0.002 \\
\hline Meyers Sheppard Pride Fund & $98-00$ & 1.27 & 5.13 & 0.079 & 0.144 & 0.005 & 0.004 & 0.009 \\
\hline MFS Union Standard Equity Fund & $98-00$ & 0.56 & 50.19 & 0.128 & 0.053 & -0.002 & 0.006 & 0.003 \\
\hline MMA Praxis Growth Fund & $99-00$ & 0.67 & 133.89 & 0.128 & 0.082 & -0.001 & 0.006 & 0.004 \\
\hline Morgan Stanley KLD Social Index/A & $02-04$ & -0.04 & 1.4 & -0.004 & -0.030 & -0.002 & -0.000 & -0.002 \\
\hline
\end{tabular}




\begin{tabular}{|c|c|c|c|c|c|c|c|c|}
\hline Fund Name & Beg-end & $\begin{array}{r}\text { Return } \\
(\%)\end{array}$ & $\begin{array}{r}\text { TNA (\$ } \\
\text { MM) }\end{array}$ & $\begin{array}{l}\text { Index- } \\
\text { Sharpe } \\
\text { ratio of } \\
\text { index }\end{array}$ & $\begin{array}{r}\text { Sharpe } \\
\text { ratio } \\
\text { for } \\
\text { fund }\end{array}$ & $\begin{array}{r}\text { Jensen's } \\
\text { alpha for } \\
\text { fund }\end{array}$ & $\begin{array}{r}\text { Treynor- } \\
\text { index for } \\
\text { market } \\
\text { portfolio }\end{array}$ & $\begin{array}{l}\text { Treynor } \\
\text { index } \\
\text { for fund }\end{array}$ \\
\hline Neuberger \& Berman NYCDC Socially Responsive & $95-98$ & 1.52 & 155.12 & 0.309 & 0.264 & -0.002 & 0.012 & 0.011 \\
\hline Neuberger \& Berman Socially Responsive Fund & $99-00$ & 1.02 & 75.92 & 0.129 & 0.147 & 0.001 & 0.006 & 0.008 \\
\hline New Alternatives Fund & $84-00$ & 0.54 & 36.8 & 0.137 & 0.039 & -0.003 & 0.006 & 0.003 \\
\hline Noah Fund & $01-03$ & 0.66 & 11.59 & 0.139 & 0.078 & -0.002 & 0.007 & 0.004 \\
\hline Noah Fund Large-Cap Growth Portfolio & $00-02$ & 0.50 & 11.29 & 0.059 & 0.015 & -0.003 & 0.001 & 0.003 \\
\hline Parnassus Fund & $87-00$ & 1.11 & 273.87 & 0.137 & 0.120 & 0.001 & 0.006 & 0.007 \\
\hline Parnassus Income fund--balanced portfolio & $97-00$ & 1.00 & 111.19 & 0.145 & 0.194 & 0.003 & 0.006 & 0.010 \\
\hline Pioneer II & $96-00$ & 0.78 & 4896.84 & 0.137 & 0.107 & -0.001 & 0.006 & 0.005 \\
\hline Pioneer Equity Income Fund/C & $98-00$ & 0.69 & 37.88 & 0.104 & 0.092 & 0.001 & 0.005 & 0.006 \\
\hline Pioneer Tax Managed Fund/C & $02-03$ & -0.29 & 4.46 & -0.019 & -0.086 & -0.003 & -0.001 & -0.005 \\
\hline Rightime Social Awareness & $93-00$ & 0.04 & 10.1 & 0.114 & -0.124 & -0.008 & 0.005 & -0.009 \\
\hline Schwartz Ave Maria Catholic Values Fund & 03-04 & 0.85 & 145.2 & -0.011 & 0.146 & 0.008 & -0.000 & 0.009 \\
\hline Security Equity Fd:Social Awareness Series/A & $99-00$ & 0.45 & 11.63 & 0.089 & 0.026 & -0.002 & 0.005 & 0.001 \\
\hline Shearson Lehman brothers strategic investor/A & $97-00$ & 0.80 & 225.87 & 0.105 & 0.128 & 0.001 & 0.005 & 0.006 \\
\hline Shearson Eq-Strategic Investors/B & $96-00$ & 0.71 & 196.14 & 0.101 & 0.106 & 0.000 & 0.004 & 0.005 \\
\hline Smith Barney Concert Social Awareness/C & $99-00$ & 0.70 & 18.86 & 0.098 & 0.094 & 0.000 & 0.005 & 0.005 \\
\hline SteinRoe Advisor Young Investor Fund/A & $98-00$ & 0.00 & 113.99 & -0.058 & -0.073 & -0.002 & -0.003 & -0.004 \\
\hline Stratton Funds:Small Cap Yield Fund & $96-00$ & 1.10 & 34.32 & 0.093 & 0.189 & 0.004 & 0.004 & 0.013 \\
\hline Stratton Growth Fund & $72-00$ & 1.04 & 43.17 & 0.137 & 0.174 & 0.003 & 0.006 & 0.010 \\
\hline TCW/DW Small Cap Growth Fund & $97-00$ & 0.94 & 305.71 & 0.083 & 0.005 & -0.005 & 0.004 & 0.000 \\
\hline Third Avenue Small-Cap Value Fund & $99-00$ & 1.07 & 271.3 & 0.084 & 0.147 & 0.005 & 0.005 & 0.010 \\
\hline Third avenue value fund & $93-00$ & 1.20 & 1323.96 & 0.137 & 0.224 & 0.004 & 0.006 & 0.012 \\
\hline TIAA-CREF Social Choice Equity Fund & $01-04$ & -0.28 & 61.81 & -0.111 & -0.106 & -0.001 & -0.006 & -0.006 \\
\hline Timothy Plan/Instl & $99-00$ & 0.73 & 15.1 & 0.129 & 0.079 & -0.002 & 0.006 & 0.005 \\
\hline USAA First Start Growth Fund & $00-02$ & 0.11 & 164.36 & 0.036 & -0.030 & -0.005 & 0.002 & -0.002 \\
\hline Vanguard Calvert Social Index Fund & $01-04$ & -0.42 & 120.3 & -0.087 & -0.107 & -0.002 & -0.005 & -0.006 \\
\hline Winslow Green Growth Fund & $01-04$ & 1.64 & 28.05 & -0.007 & 0.140 & 0.012 & -0.000 & 0.009 \\
\hline
\end{tabular}




\section{Table 2}

\section{Portfolios of SRI funds}

'Portfolio 1' is formed by investing an equal amount each month, starting in January of 1992 and ending in December of 2003, in each SRI fund that is available,. 'Portfolio 2' is formed as follows: each month, I invest $\$ 100$ in a portfolio consisting of a $\$ 1$ investment in each of the SRI funds that were available as of the start of that calendar year, and the rest is invested in the CRSP value-weighted index. If a fund ceases to exist in any month following January of that year, I set its return equal to the CRSP valueweighted index return. It is eliminated from the portfolio in January of the following year and thereafter. Mean and median returns to the two portfolios are reported in the table. The table also reports the Sharpe ratio, the Treynor index and Jensen's alpha for these two portfolios. Monthly fund returns are obtained from the CRSP Mutual Fund Database, and the return to the CRSP value-weighted index is from the Fama-French dataset.

\begin{tabular}{|l|llllll|}
\hline Portfolio & $\begin{array}{l}\text { Mean } \\
\text { monthly } \\
\text { portfolio } \\
\text { return }\end{array}$ & $\begin{array}{l}\text { Median } \\
\text { monthly } \\
\text { portfolio } \\
\text { return }\end{array}$ & $\begin{array}{l}\text { Standard } \\
\text { deviation of } \\
\text { monthly } \\
\text { portfolio } \\
\text { returns }\end{array}$ & $\begin{array}{l}\text { Sharpe } \\
\text { Ratio }\end{array}$ & $\begin{array}{l}\text { Treynor's } \\
\text { index }\end{array}$ & $\begin{array}{l}\text { Jensen's } \\
\text { alpha }\end{array}$ \\
\hline Portfolio 1 & 0.0080 & 0.0097 & 0.0560 & 0.1365 & 0.0060 & 0.0001 \\
Portfolio 2 & 0.0091 & 0.0136 & 0.0417 & 0.1405 & 0.0061 & 0.0002 \\
$\begin{array}{l}\text { CRSP } \\
\text { Value- } \\
\text { weighted } \\
\text { index }\end{array}$ & 0.0093 & 0.0141 & 0.0435 & 0.1370 & 0.0060 & NA \\
\hline
\end{tabular}




\section{Table 3}

\section{Factor Loadings of the SRI portfolio}

In each month, starting in January of 1992 and ending in December of 2003, I invest $\$ 100$ in 'Portfolio 2' which consists of a \$1 investment in each of the SRI funds that were available as of the start of that calendar year, and any amount left over is invested in the CRSP value-weighted index. If a fund ceases to exist in any month following January of that year, we set its return equal to the CRSP value-weighted index return. It is eliminated from the portfolio in January of the following year and thereafter. The monthly returns to this modified portfolio in excess of the risk free rate, are regressed on the returns to various portfolios. In the first regression, the independent variables are the three Fama-French factors (1996), the excess return to the market portfolio (MKTRF), the return to a portfolio of small firms less the return to a portfolio of large firms (SMB) and the return to a portfolio of value firms less the return to a portfolio of growth firms (HML). In the second regression, the independent variables are the three Fama-French factors, and the return to the Vanguard Bond Index Fund: Total Bond Market Portfolio.

\section{Panel A: Three-factor model}

\begin{tabular}{|l|r|r|}
\hline Independent Variable & Coefficient & T-statistic \\
\hline Intercept & -0.001 & -1.40 \\
MKTRF & 0.927 & 75.16 \\
SMB & 0.140 & 11.01 \\
HML & 0.052 & 3.27 \\
observations & 143 & \\
Adj R-square & $98.26 \%$ & \\
\hline
\end{tabular}

\section{Panel B: Four-factor model}

\begin{tabular}{|l|r|r|}
\hline Independent Variable & Coefficient & T-statistic \\
\hline Intercept & -0.0003 & -0.61 \\
MKTRF & 0.9292 & 75.26 \\
SMB & 0.1384 & 10.87 \\
HML & 0.0546 & 3.44 \\
BONDRET & -0.0644 & -1.55 \\
observations & 143 & \\
Adj R-square & $98.27 \%$ & \\
\hline
\end{tabular}


Table 4

SRI fund returns and Business Cycles

In each month, starting in January 1992 and ending in December 2000, we estimate a regression of the returns to 'Portfolio 2', on the three Fama-French (1996) factors, and on the return to the Vanguard Total Bond Market Portfolio (BONDRET). The residuals obtained from this regression (SRI-RESIDUAL) are the exogenous variables in a generalized method of moments (GMM) regression estimated as:

$\begin{cases}\text { SRI }- \text { RESIDUAL } & =\mathrm{a} 0+\mathrm{a} 1 * \mathrm{LDIV}+\mathrm{a} 2 * \mathrm{LTB}+\mathrm{a} 3 * \mathrm{LDEF}+\mathrm{a} 4 * \mathrm{LTERM} \\ \text { MKTRF } & =\mathrm{b} 0+\mathrm{b} 1 * \mathrm{LDIV}+\mathrm{b} 2 * \mathrm{LTB}+\mathrm{b} 3 * \mathrm{LDEF}+\mathrm{b} 4 * \mathrm{LTERM}\end{cases}$

where MKTRF is the excess return to the market portfolio, LDIV is the lagged dividend yield on the S\&P 500, LTERM is the lagged yield spread between the ten-year Treasury bond and the three month T-bill, LTB is the lagged yield on the one-month T-bill, and LDEF is the lagged yield spread between an index of ten-year corporate bonds rated BBB and lower, and the ten year Treasury bond. Wald statistics are reported for tests of equality of the individual coefficients: $\mathrm{a} 1=\mathrm{b} 1 ; \mathrm{a} 2=\mathrm{b} 2 ; \mathrm{a} 3=\mathrm{b} 3$; $\mathrm{a} 4=\mathrm{b} 4$ and for the test that a1-b1, a2-b2, a3-b3 and a4-b4 are jointly equal to zero.

\section{Panel A: GMM coefficients}

\begin{tabular}{|l|rr|}
\hline Coefficient label & Coefficient & T-statistic \\
\hline a0 & 0.0025 & 0.71 \\
b0 & 0.0319 & 1.19 \\
a1 & 0.0032 & 0.20 \\
b1 & 0.0689 & 0.73 \\
a2 & -0.1942 & -0.25 \\
b2 & -4.2694 & -0.73 \\
a3 & -0.0139 & -1.38 \\
b3 & 0.1174 & 1.63 \\
a4 & -0.0116 & -0.98 \\
b4 & -0.1404 & -1.96 \\
Adj R-square for SRI- & & \\
RESIDUAL & $0.55 \%$ & \\
Adj R-square for MKTRF & $3.99 \%$ & \\
\hline
\end{tabular}

\section{Panel B: Wald tests}

\begin{tabular}{|l|rr|}
\hline Hypothesis & $\begin{array}{r}\text { Wald } \\
\text { statistic }\end{array}$ & prob $>\chi^{2}$ \\
\hline a1-b1=0,a2-b2=0, & & \\
a3-b3=0,a4-b4=0 & 10.88 & 0.02 \\
a1-b1 =0 & 0.45 & 0.50 \\
a2-b2=0 & 0.15 & 0.70 \\
a3-b3=0 & 3.74 & 0.05 \\
a4-b4 $=0$ & 2.34 & 0.13 \\
\hline
\end{tabular}




\section{Table 5}

\section{SRI fund returns, business cycles and sensitivity to changing risk aversion}

In each month, starting in January 1992 and ending in December 2000, we estimate a regression of the returns to 'Portfolio 2', on the three Fama-French (1996) factors, and on the return to the Vanguard Total Bond Market Portfolio (BONDRET). The residuals obtained from this regression (SRI-RESIDUAL) are the exogenous variables in a generalized method of moments (GMM) regression estimated as:

$$
\begin{cases}\text { SRI-RESIDUAL } & =\mathrm{a} 0+\mathrm{a} 1 * \mathrm{LDIV}+\mathrm{a} 2 * \mathrm{LTB}+\mathrm{a} 3 * \mathrm{LDEF}+\mathrm{a} 4 * \mathrm{LTERM}+\mathrm{a} 5 * \mathrm{INVW} \\ \text { MKTRF } & =\mathrm{b} 0+\mathrm{b} 1 * \mathrm{LDIV}+\mathrm{b} 2 * \mathrm{LTB}+\mathrm{b} 3 * \mathrm{LDEF}+\mathrm{b} 4 * \mathrm{LTERM}+\mathrm{b} 5 * \text { INVW }\end{cases}
$$

where MKTRF is the excess return to the market portfolio, LDIV is the lagged dividend yield on the S\&P 500, LTERM is the lagged yield spread between the ten-year Treasury bond and the three month T-bill, LTB is the lagged yield on the one-month T-bill, and LDEF is the lagged yield spread between an index of ten-year corporate bonds rated BBB and lower, and the ten year Treasury bond. INVW is the proxy for relative risk aversion calculated as the ratio of the exponentially weighted average of the past 36 months of real wealth levels to the one-period lag of real wealth. The inflation-adjusted level of the S\&P 500 is our proxy for the real wealth level. Wald statistics are reported for tests of hypotheses on individual coefficients: $a 1=b 1 ; a 2=b 2 ; a 3=b 3 ; a 4=b 4 ; a 5=b 5$ and for the test that a1-b1, a2-b2, a3-b3, a4-b4 and a5-b5 are jointly equal to zero.

\section{Panel A: GMM coefficients}

\begin{tabular}{|l|r|r|}
\hline Coefficient label & Coefficient & T-statistic \\
\hline a0 & -1.5540 & -3.85 \\
b0 & 0.2223 & 0.06 \\
a1 & -0.0060 & -0.49 \\
b1 & 0.0448 & 0.50 \\
a2 & 0.3197 & 0.41 \\
b2 & -4.5903 & -0.76 \\
a3 & -0.0246 & -2.30 \\
b3 & 0.1339 & 1.59 \\
a4 & -0.0179 & -1.72 \\
b4 & -0.1232 & -1.77 \\
a5 & -0.2415 & -3.85 \\
b5 & 0.0292 & 0.05 \\
Adj R-square for SRI-RESIDUAL & $0.43 \%$ & \\
Adj R-square for MKTRF & $4.03 \%$ & \\
\hline
\end{tabular}

\section{Panel B: Wald tests}

\begin{tabular}{|l|r|r|}
\hline Hypothesis & Wald statistic & prob $>\chi^{2}$ \\
\hline a1-b1=0,a2-b2=0,a3-b3=0,a4-b4=0,a5-b5=0 & 11.11 & 0.05 \\
a1-b1=0 & 0.31 & 0.58 \\
a2-b2=0 & 0.64 & 0.42 \\
a3-b3=0 & 3.28 & 0.07 \\
\hline a4-b4=0 & 2.13 & 0.14 \\
a5-b5=0 & 0.18 & 0.67 \\
\hline
\end{tabular}




\section{Table 6}

\section{Trading Strategies}

Profitability of a trading strategy is evaluated. Every month, starting in January of 1994 and ending in December of 2000, the difference between the monthly return to the modified SRI portfolio and the return to the market portfolio, 'SRI-MKT' is calculated. The difference in returns in the previous 24 months, is regressed on business cycle variables, and on the proxy for relative risk aversion. The business cycle variables are lagged dividend yield (LDIV), the lagged yield spread between the ten-year Treasury bond and the three month T-bill (LTERM), the lagged yield on the one-month T-bill (LTB), and the lagged yield spread between an index of ten-year corporate bonds rated BBB and lower and the ten year Treasury bond (LHB3). INVW is the proxy for relative risk aversion calculated as the ratio of the exponentially weighted average of the past 36 months of real wealth levels to the current level of real wealth. The predicted monthly returns to the 'SRI-MKT' portfolio from the 24-month rolling regressions are obtained. The table reports the average return to the 'SRI-MKT' portfolio in those months when the predicted return in the previous month is positive.

Panel A: Independent variables include only business cycle variables

\begin{tabular}{|r|r|r|r|r|}
\hline Observations & $\begin{array}{r}\text { mean } \\
\text { return to } \\
\text { SRI-MKT }\end{array}$ & $\begin{array}{r}\text { median } \\
\text { return to } \\
\text { SRI-MKT }\end{array}$ & $\begin{array}{r}\text { t-statistic } \\
\text { for mean }\end{array}$ & signed rank test \\
\hline 38 & 0.00324 & 0.000482 & 2.43 & prob=0.04 \\
\hline
\end{tabular}

Panel B: Independent variables include business cycle variables and a proxy for relative risk aversion

\begin{tabular}{|r|r|r|r|r|}
\hline Observations & $\begin{array}{r}\text { mean } \\
\text { return to } \\
\text { SRI-MKT }\end{array}$ & $\begin{array}{r}\text { median } \\
\text { return to } \\
\text { SRI-MKT }\end{array}$ & $\begin{array}{r}\text { t-statistic } \\
\text { for mean }\end{array}$ & signed rank test \\
\hline 38 & 0.0027 & 0.00048 & 1.91 & prob=0.11 \\
\hline
\end{tabular}

